\title{
Development of pedal operated thresher for finger millets
}

\section{PARMANAND, AJAY VERMA, P.D. VERMA AND PRABHAT KUMAR GURU}

See end of the Paper for authors' affiliation

Correspondence to :

\section{PARMANAND}

Krishi Vigyan Kendra, BHATAPARA (C.G.) INDIA

Email : erparmanandsahu@ gmail.com
-ABSTRACT : This paper deals with the development of a pedal operated millet thresher. Millet is one of the oldest human foods and believed to be the first domesticated cereal grain. Millets are important food for sustaining tribal population in Bastar region of Chhattisgarh. Available evidence suggests that the mode of threshing finger millet is by traditional method like beating with sticks, rubbing and trampling finger-heads under bullocks feet or men feet. Traditional method is time wasting, energy sapping and often the grains are broken. Pedal operation is the most efficient way of utilizing power from human muscles. Keeping this thing in mind, pedal operated thresher for minor millets with spike-tooth type threshing cylinder was designed, fabricated and tested. This machine basically consists of four major components: feeding, threshing (consisting of threshing cylinder, concave and cylinder casing), cleaning and power transmission mechanism. The developed millet thresher has the ability to winnow the premature grains and leaves, which are often lighter, thus, leaving aside the massy grains that, will be collected. It is beneficial for farmers with reduced time of operation, reduction in breakage of the grains and separation of the stalk from the grains. The machine is economically viable can be used by farmers easily.

- KEY WORDS : Finger millet thresher, Spike-tooth type threshing cylinder, Pedal operated thresher

- HOW TO CITE THIS PAPER : Parmanand, Verma, Ajay, Verma, P.D. and Guru, Prabhat Kumar (2015). Development of pedal operated thresher for finger millets. Internat. J. Agric. Engg., 8(2) : 175-180. 